\title{
EVALUATING THE IMPLEMENTATION OF QUALITY MANAGEMENT SYSTEMS IN SUPPLY NETWORKS IN BRAZIL
}

\author{
João Gilberto Mendes dos Reis \\ Universidade Federal da Grande Dourados - UFGD, Brazil \\ Universidade Paulista - UNIP, Brazil \\ E-mail: betomendesreis@msn.com \\ Pedro Luiz de Oliveira Costa Neto \\ Universidade Paulista - UNIP, Brazil \\ E-mail: politeleia@uol.com.br \\ Sivanilza Teixeira Machado \\ Universidade Federal da Grande Dourados - UFGD, Brazil \\ E-mail: sivateixeira@yahoo.com.br \\ Rone Vieira Oliveira \\ Universidade Federal da Grande Dourados - UFGD, Brazil \\ E-mail: rone.vieira.oliveira@hotmail.com
}

\section{M.1979}

Submission: $27 / 09 / 2013$

Revision: $17 / 10 / 2013$

Accept: 01/11/2013

\section{ABSTRACT}

The development of relationships between organizations through Supply Chain Management, with a view to delivering products and services and consumers has led quality management to go beyond the boundaries of the individual firm and thus spread to the various network actors in which the organization is involved. This has been called Supply Chain Quality Management (SCQM) and consists in developing a quality policy applicable to the whole supply chain. Quality management systems have been successfully implemented within individual companies, but how has this actually affected suppliers, within SCM? This paper conducted a survey in thirteen companies operating in Brazil to assess the effectiveness of SCQM. The results show that companies are still very concerned about quality within their individual companies and ensuring quality from their suppliers still involves performance indicators and depends on the availability of 
INDEPENDENT JOURNAL OF MANAGEMENT \& PRODUCTION (IJM\&P)

http://www.ijmp.jor.br

v. 5, n. 2, February - May 2014.

ISSN: 2236-269X

DOI: 10.14807/ijmp.v5i2.146

suppliers for each item required.

Keywords: supply chain quality management; quality management systems; Brazilian companies

\section{INTRODUCTION}

Quality assurance systems are an integral part of today's industrial processes and service operations and therefore can not be viewed as systems that are disassociated from the universe of operations. Accordingly, production engineers and operations have had to implement systems that enable the customers to have a perception of the quality of the products and service that they receive.

As a result, many systems have been developed, such as Total Quality Management, Six Sigma, ISO 9000 standards, Hoshin Kanri, Quality Awards, among others (FEIGENBAUM, 1994; CAMPOS, 2004; AKPOLAT, 2004; SAMPAIO et al., 2009; MEHRJERDI, 2011).

Though these may differ in certain aspects, their objectives remain the same, and it is possible to find many cases of successful application of these systems in different companies around the globe. After the 1990s, an increase in the quantity of information from companies and customers was observed as well as the development of tools like the Internet have contributed to greater knowledge of products and services by customers who buy from the companies who have become more demanding as to the quality of such products, and with regard to reductions in price.

The level of competitiveness thus generated caused organizations to begin to monitor their suppliers and their distribution processes better, through management of their supply chains. This process led to competitiveness being between the levels of the chains and no longer just between companies (CHOPRA; MEINDL, 2011).

Quality management systems went beyond the boundaries of the individual firms, and began to spread throughout the network for supplies that make up the production of a given product or service. This advance in quality management systems across company borders has been named Supply Chain Quality Management (SCQM). 
INDEPENDENT JOURNAL OF MANAGEMENT \& PRODUCTION (IJM\&P) http://www.ijmp.jor.br

v. 5, n. 2, February - May 2014. ISSN: 2236-269X

DOI: 10.14807/ijmp.v5i2.146

This paper propose to study the concepts of SCQM and assess how some companies operating in Brazil have adopted quality management systems throughout their supply networks.

\section{LITERATURE REVIEW}

\subsection{Supply Chain Management}

Supply Chain Management (SCM) consists of coordinating relationships between companies within the same network, with a view to maximizing the profits of the members, through an improved and cooperative relationship. This allows the supplier companies in the network to deliver better products and services to end consumers at more competitive prices. These networks are composed of sets of customers and suppliers, responsible for the flow of goods, from the origin of the raw materials to the end user.

Costa Neto and Canuto (2010) emphasize that supply chains entail the flow of products, starting from the raw materials to products and services at the point of sale, and that the whole system of companies and activities has a sum of costs plus expenses which are necessary for the entire system to function, of which the customer is the most important in all of this process, because that is who pays all the bills. Figure 1 shows the flow of products and services, and the flow of information within a supply chain.

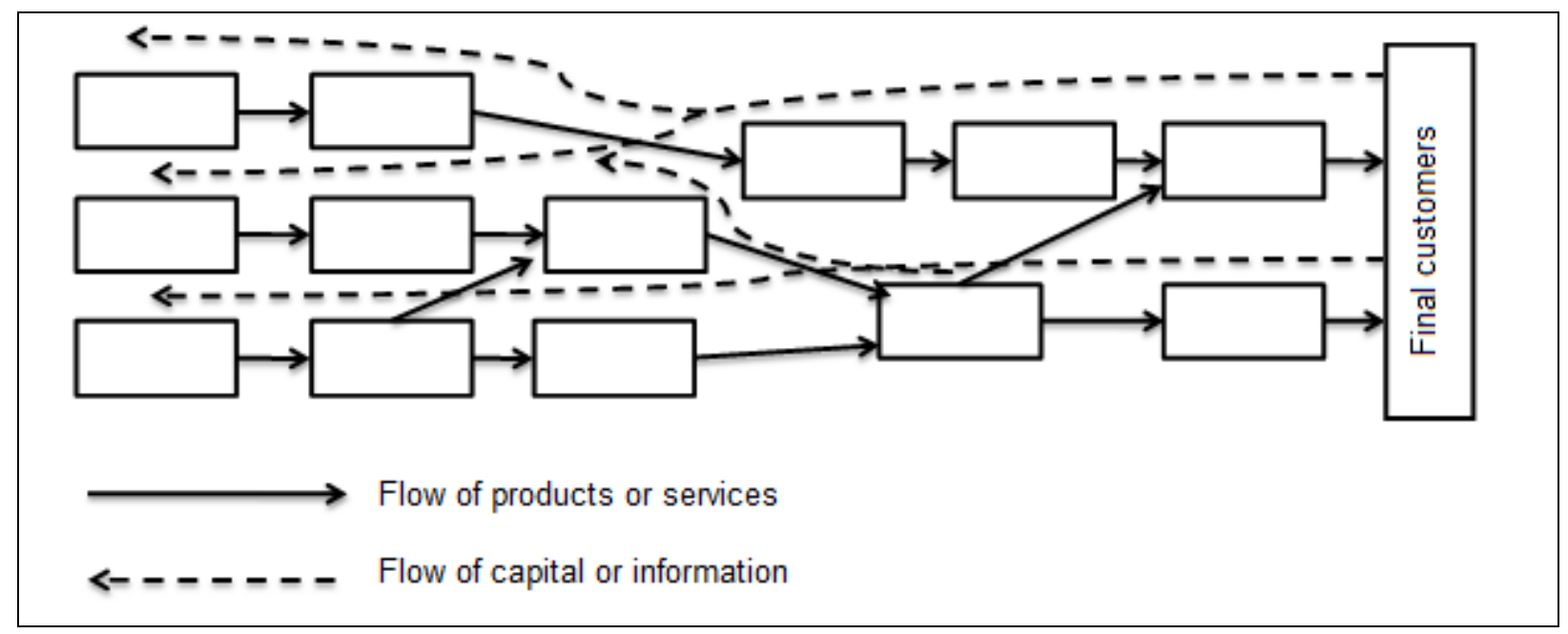

Figure 1: Flows in the Supply Network.

Source: Adapted from Costa Neto and Canuto (2010).

The evolution of concepts of network between companies changed ideas about competitiveness, which was no longer considered as a dispute between 
INDEPENDENT JOURNAL OF MANAGEMENT \& PRODUCTION (IJM\&P) http://www.ijmp.jor.br

v. 5, n. 2, February - May 2014. ISSN: 2236-269X

DOI: 10.14807/ijmp.v5i2.146

companies but reached the level of competition between supply chains, even when parts of the elements in such networks are common to several chains and are shared (CORRÊA, 2010), making managing such chains essential.

A supply chain can be conceptualized as being all parties involved, directly or indirectly, in filling the order from a particular customer (CHOPRA; MEINDL, 2011). The parts produce an interaction that can be managed. This management of supply chains is known as management of upstream and downstream relationships, and its purpose is to deliver superior value to the customer at the lowest cost for the entire supply chain (CHRISTOPHER, 2011).

\subsection{Supply Chain Quality Management}

The quality of products and services has been studied for many years. The discovery that the quality of products and services is linked to the manufacturing processes and the way of providing services culminated in studies, techniques, systems and tools being developed, aimed at improving the processes and operations, in order to obtain the desired end result. However, the network environment has changed this scenario because we can no longer think of the quality by focusing on individual processes. With competitiveness between networks, it is necessary to observe quality within this new context, to understand how it is established in the competitive environment.

Despite the importance of quality in company networks, the issue has not been addressed in major industry publications, among which one can cite Pires (2009), Corrêa (2010), Christopher (2011), Chopra and Meindl (2011). Such publications conceptualize networks, map their processes, study their risks and deal with performance evaluations, but do not deal with quality in particular.

Thus, this gap has been covered by the academic community based on scientific articles that address the issue of quality in the universe of networks. Among the studies reviewed in various journals, the most important are the research from Beamon and Ware (1998), Kuei et al. (2001), Robinson and Malahotra (2005), Lin et al. (2005), Sila et al. (2006), Foster Jr. (2008), Kaynak and Hartley (2008), Carmignani (2009), Zu and Kaynak (2012), Lin et al. (2013). 
Kaynak and Hartley (2008) argue that the competition has moved beyond the individual company to the supply chain, in which context the researchers begin to explore the issue of quality management. They believe that two management practices, directly impact the quality of the network, known as "quality supply management and customer focus." Lin et al. (2005) agree with Kaynak and Hartley (2008) that SCQM is influenced by two quality management practices: management of the quality of the suppliers and their participation in the tangible business results, along with the level of customer satisfaction.

The authors also claim that quality in the supply network is a key component in achieving a competitive advantage. Kuei et al. (2001) claim that, in the digital age, SCQM has been recognized as one of the most important ways to respond quickly, correctly and profitably to the demands of the market.

Sila et al. (2006) infer that the first step toward SCQM was given by organizations when they began to not only control their quality, but also began to determine the quality of their direct partners. According to Lin et al. (2013) modern enterprises need to pay immediate attention to SCQM through following to path ways: a compliance approach and a voluntary approach.

Robinson and Malahotra (2005) state that traditional quality programs focus on approaches such as Total Quality Management, the Malcolm Baldrige Award and ISO 9001, and should transform themselves into a network perspective. Thus, SCM must encompass quality initiatives, however, this is only one aspect that programs to continuously improve quality must address in order to achieve competitive leadership.

In addition, Zu and Kaynak (2012) proposes an interesting methodology that allow create a conceptual framework that relates the underlying factors of a supply chain relationship to the use of quality management approaches.

According to Robinson and Malahotra (2005), SCQM can be defined as formal coordination and integration of business processes that involve all partners in the supply channel organization to analyze, measure and continuously improve products, services and processes, in order to create value and achieve satisfaction of intermediate and final customers. 
INDEPENDENT JOURNAL OF MANAGEMENT \& PRODUCTION (IJM\&P)

http://www.ijmp.jor.br

v. 5, n. 2, February - May 2014.

ISSN: 2236-269X

DOI: 10.14807/ijmp.v5i2.146

Foster Jr. (2008) argue that the SCQM is a system based on a performance improvement approach that leverages opportunities created downstream and upstream in the supply chain, with both suppliers and customers. Thus, one can infer that SCQM is the natural evolution of quality systems toward company network environments (Table 1).

Table 1: Evolution of Quality Management Systems

\begin{tabular}{|c|c|c|c|c|c|}
\hline Year & $1920-1960$ & $1960-1980$ & $1980-1990$ & $1990-2004$ & $\begin{array}{c}2004 \text { and } \\
\text { Beyond }\end{array}$ \\
\hline Program & $\begin{array}{l}\text { Control charts } \\
\text { Statistical } \\
\text { process control } \\
\text { (SPC) } \\
\text { Inspections }\end{array}$ & $\begin{array}{l}\text { Zero Defects; } \\
\text { Troubleshooting } \\
\text { Quality Circles } \\
\text { Statistical } \\
\text { process control } \\
\text { (SPC) } \\
\text { Experimental } \\
\text { projects }\end{array}$ & $\begin{array}{c}\text { TQM } \\
\text { ISO } 9001 \\
\text { Malcolm } \\
\text { Baldrige Award } \\
\text { Six Sigma }\end{array}$ & $\begin{array}{l}\text { Supply Chain } \\
\text { Management }\end{array}$ & $\begin{array}{l}\text { Supply Chain } \\
\text { Quality } \\
\text { Management } \\
\text { (SCQM) }\end{array}$ \\
\hline Focus & $\begin{array}{c}\text { Internal } \\
\text { organization. }\end{array}$ & $\begin{array}{c}\text { Internal } \\
\text { organization }\end{array}$ & $\begin{array}{l}\text { Supply base } \\
\text { Internal } \\
\text { organization } \\
\text { Customers' } \\
\text { expectations }\end{array}$ & $\begin{array}{l}\text { All actors in } \\
\text { the supply } \\
\text { chain and } \\
\text { primarily } \\
\text { internal } \\
\text { organization. }\end{array}$ & $\begin{array}{l}\text { All actors in the } \\
\text { supply chain } \\
\text { and primarily } \\
\text { external } \\
\text { organizations }\end{array}$ \\
\hline
\end{tabular}

Source: Adapted from Robinson and Malahotra (2005)

\subsection{Quality Management Systems}

Several quality management systems have been used by organizations; the most noteworthy are the following: Total Quality Management (TQM), Six Sigma, ISO Standards, Quality Awards, Hoshin Kanri.

\subsubsection{Total Quality Management}

The Total Quality Management has its origin in Total Quality Control (TQC), and an administrative system perfected in Japan from American ideas. Initially developed by Armand Feigenbaum, TQC practiced in Japan is different from that [originally] proposed because it is based on the participation of all sectors of the company and all the employees in studying and performing quality control. 
INDEPENDENT JOURNAL OF MANAGEMENT \& PRODUCTION (IJM\&P) http://www.ijmp.jor.br

v. 5, n. 2, February - May 2014. ISSN: 2236-269X

DOI: 10.14807/ijmp.v5i2.146

The Japanese TQC became known in the West as CWQC Company-Wide Quality Control (CAMPOS, 2004). According to Miguel (2006), the evolution of TQC resulted in TQM. The main idea of TQM is that quality is present in the function of organizational management, with the objective of broadening its focus, rather than merely limited to control.

Hur (2009) after a careful study explain that TQM can be dividing in three dimensions: Employee empowerment - hability of workforce meet the customer requirements, Understanding - perception of quality with which customers are satisfied and finally continuous organizational improvement. All these characteristics are important to get the total quality management.

\subsubsection{Six Sigma}

Concerning the Six Sigma conception, the quality is almost always associated with the perception of each individual client, so a service performed or a product sold may be good for one person and bad for another. Therefore, there is a change in perceived quality from one customer to another. However, this difference in perception is not necessarily related to a personal vision, but rather variations in product specifications or in the way of providing the service.

This variation can occur in several ways. If variation is a problem, what is the way to control it to improve the quality of products and services? It is in response to that question that the system known as Six Sigma arose. The Six Sigma program, according to Mehrjerdi (2011), is credited to Dr. Mike Harry, a statistician who was the principal founder of the Six Sigma Academy in Scottsdale, Arizona, United States. Motorola was the first U.S. Company to adopt the system, followed by other organizations such as General Electric (GE) and Texas Instruments. The idea behind the application consists of using statistical tools to reduce process variations.

For instance, we can measure the quality of system using average of process and your standard deviation. The name six sigma, derives of deviation of process. The idea consists that to avoid failures is necessary ensure six times standard deviation of process (Figure 2). This situation is equivalent a three or four parts per million (ppm). 


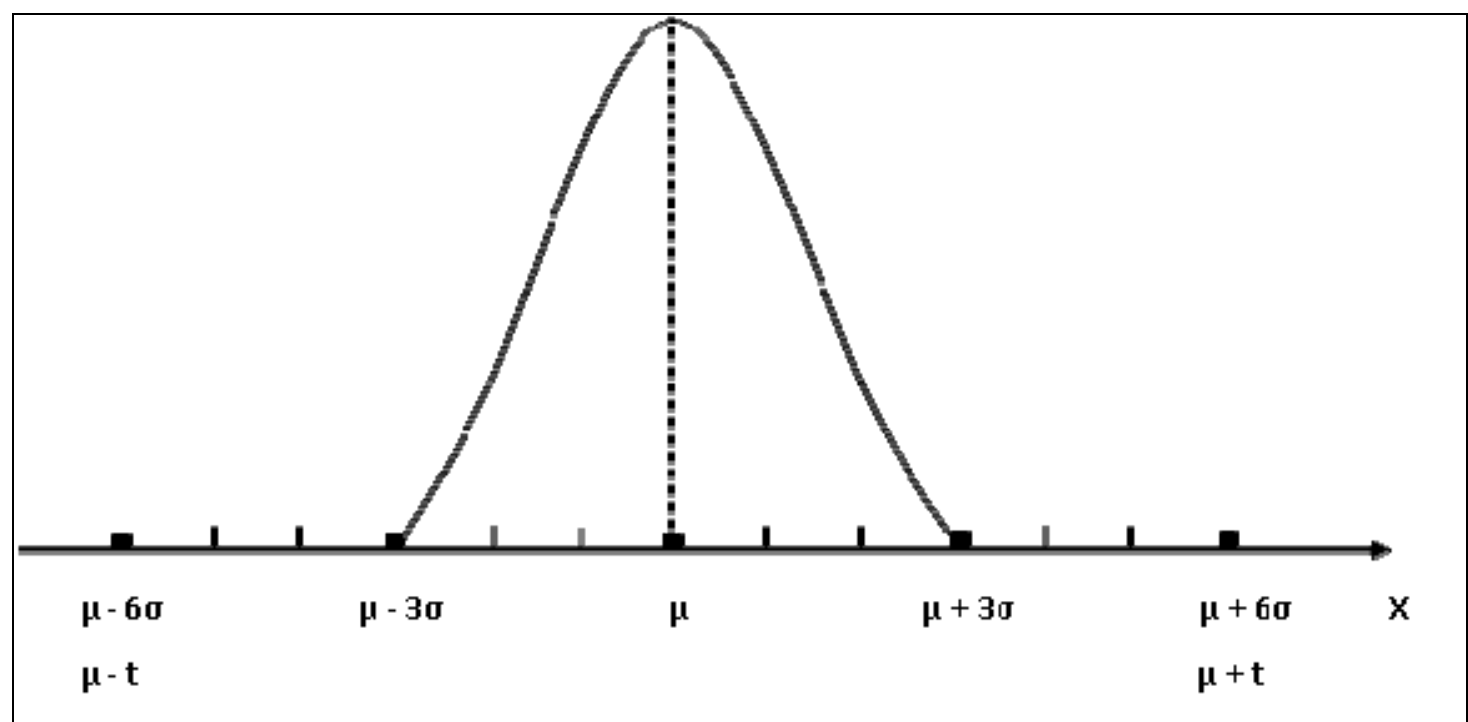

Figure 2: Six Sigma Conditional.

Source: Adapted from Costa Neto and Canuto (2010).

\subsubsection{ISO Standards}

The search to define quality standards that can be applied to different organizations and guarantee the uniformity of quality parameters, and at the same time determine indicators for organizations, led to the emergence of so-called Quality Standards. Companies meeting the requirements of such standards can be certified by a reputable institution.

Such institution certifies that organizations comply with the items set forth in the standard, thus ensuring quality in the organization. A standard is a document established by consensus and approved by a recognized body, that provides rules and guidelines for activities or the results thereof (FERREIRA, 2005).

The International Organization for Standardization (ISO) is an international non-governmental organization made up of a network of standardization institutes, one per country. Headquartered in Geneva, Switzerland, it is made up of 162 countries and sets international standards, including quality standards (ISO, 2013). The ISO 9000 series, a designation given to quality management systems, emerged in 1987 and became a worldwide phenomenon showing tremendous growth and dissemination across different countries (SAMPAIO et al., 2009). The ISO 9000 series, according to Ferreira (2005), consists of three main standards: ISO 9000 Quality Management Systems - Fundamentals and Vocabulary; ISO 9001 - Quality 
INDEPENDENT JOURNAL OF MANAGEMENT \& PRODUCTION (IJM\&P) http://www.ijmp.jor.br

v. 5, n. 2, February - May 2014. ISSN: 2236-269X

DOI: 10.14807/ijmp.v5i2.146

Management Systems - Requirements; and ISO 9004 - Quality Management Systems - Guidelines for performance improvements

\subsubsection{Quality Awards}

Quality awards were created in order to enhance the efforts of organizations towards achieving excellence in their products and processes. The first of these, called the Deming Prize, named after the American master who greatly contributed to its improvement, was introduced in Japan in 1951, honoring companies and persons related to quality control.

After many years, prizes began to emerge valuing management excellence, such as the American Malcolm Baldrige Award and, in Brazil, the Prêmio Nacional da Qualidade - PNQ (National Quality Award), which came about between 1988 and 1992 (COSTA NETO, 2007). Unlike ISO 9000 standards, which certify the fundamentals of quality management, these awards cover excellence in management as a whole, and are only given to companies considered world class.

\subsubsection{Hoshin Kanri}

Another way to manage an organization based on the quality of its products and services is policy deployment, known in Japan as Hoshin Kanri. This is an administrative system practiced by the whole organization with the objective of ensuring survival in the international market. According to Campos (2004), policy deployment is a management system that leads to the establishment and carrying through of an annual plan.

Accordingly, annual goals are the starting point for such management systems. Policy deployment seeks to identify the causes which make it impossible to meet targets and establishes countermeasures to achieve objectives by improving and implementing products and processes.

\section{METHODOLOGY}

Companies from different segments were evaluated to determine the effectiveness of the application of quality management in their networks. Thus, this work is divided into the following stages: 
(a) Bibliographical research in order to understand the concept of networks and ideas on Supply Chain Quality Management and Quality Management Systems.

(b) Subsequently, performing research in the field on companies operating in Brazil, both of Brazilian origin and transnational, to identify whether systems for coordination between supply chains and quality management systems across the company and its suppliers had been adopted.

(c) Analysis of the results obtained.

\section{FIELD SURVEY AND DISCUSSION OF RESULTS}

\subsection{Field survey: companies}

This research was conducted in thirteen companies operating in various sectors of Brazil. For each company, we tried to identify where supply management techniques for their supply chains had been adopted, along with the implementation of quality systems within the organization, and quality systems for other actors in the network.

Companies were classified into sectors by adopting the criteria from the Brazilian Geography and Statistics Institute - IBGE (2007), which classifies and defines economic sectors for statistical analysis to be used in Brazil; along with the definitions established by the Federation of Industries of the State of São Paulo FIESP (2013). Accordingly, the sample was divided up in accordance with Figure 3.

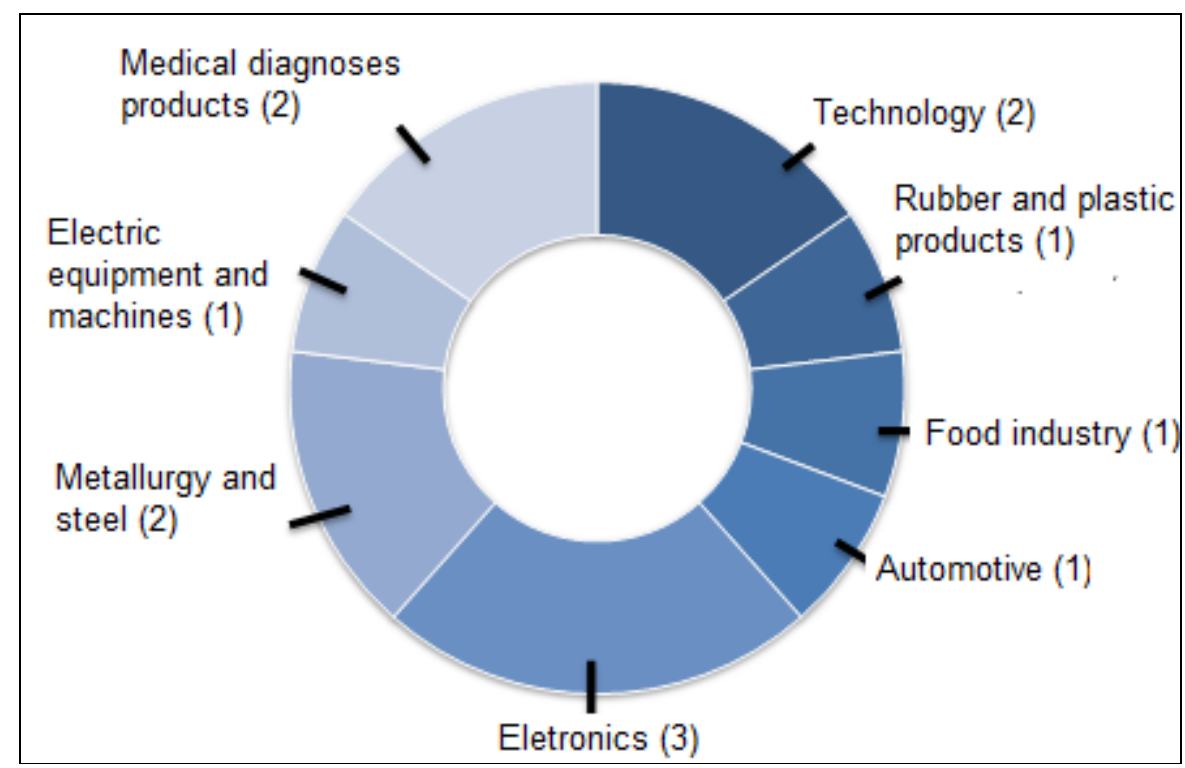

Figure 3: Companies Taking part in the Research, by Sector. 
Of the thirteen companies surveyed, eight are multinational and have facilities in more than one region of Brazil; the others are of Brazilian origin.

\subsection{Supply Chain Management}

Companies were evaluated as to whether they carried out supply chain management, i.e., if they managed the network within which they operate. This assessment was done jointly with an evaluation of the degree of vertical integration that the companies involved have adopted. The results obtained are shown in Figure 4.

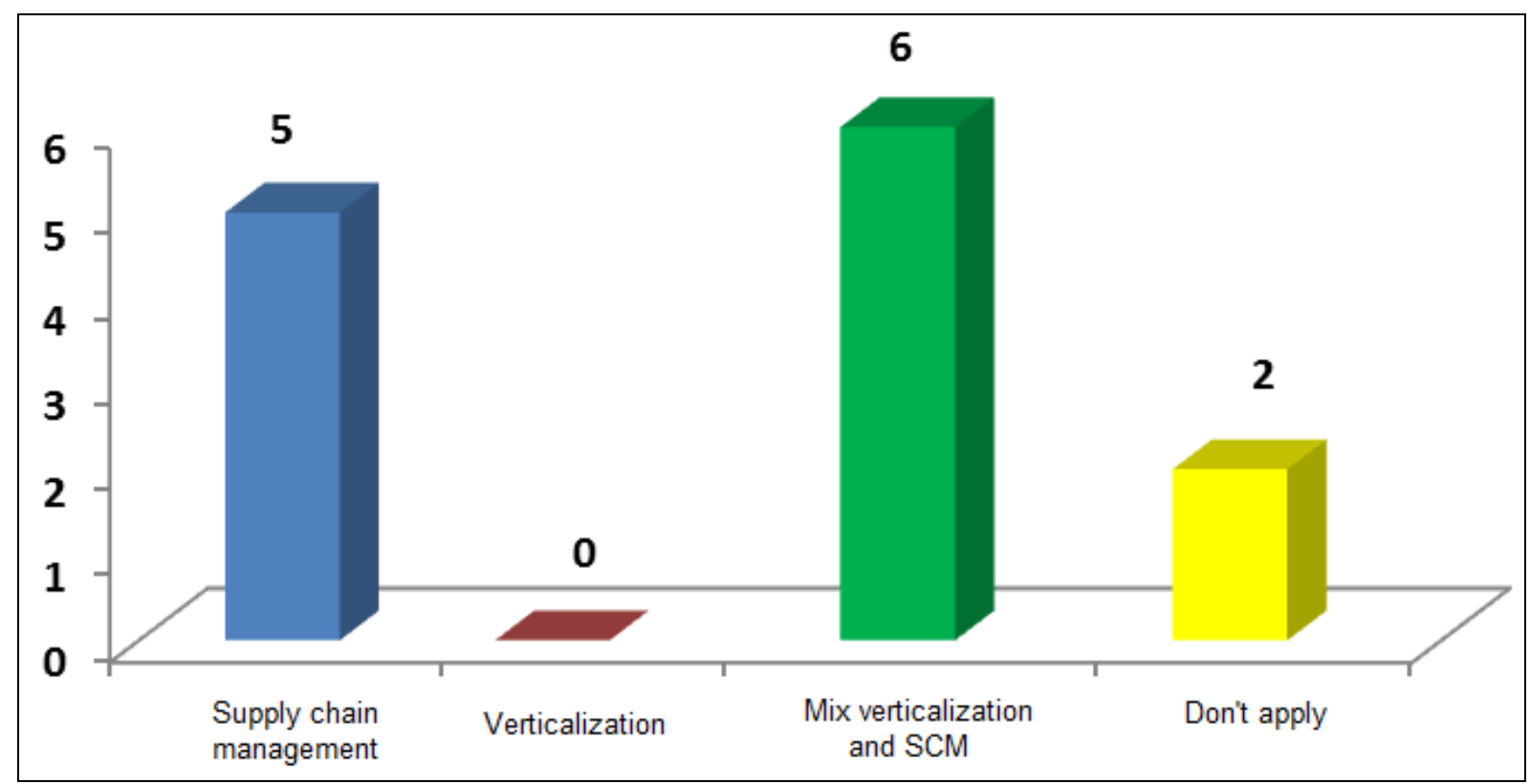

Figure 4: Supply Chain Management and Verticalization.

The research found that $46 \%$ of companies have adopted management of their supply network, but with some kind of vertical integration process. Already $38 \%$ of companies say they manage their supply chains without verticalizing their processes. Another $15 \%$ say they do not perform network management or verticalize their processes, but merely purchase their raw materials at the lowest price and carry out their own transformation process.

None of the companies surveyed claimed to be totally vertical, as the companies buy most of the raw materials they need and verticalize what they consider strategic or which they have no supplier for. Of the 11 companies that claimed to manage the supply chain, it was observed in the field that five of them are 
responsible for managing their entire network, so they are the hubs of the chain to which they belong.

The three companies in the electronics sector and one food company, who claimed to manage their supply chains, actually managed their suppliers and the quality assurance of the final product. The company which is the hub of the network is responsible for retail, and determines the quantities to be sold and the gains to be obtained from the network. Retail chains like Walmart, for example, are larger than most of their suppliers, thereby serving as the hub for the supply networks in which they participate.

With respect to the other two companies that adopt the management of the supply network, one affirmed that this was more of a concept than an actual practice whilst another actually manages its suppliers, because it is the [main] actors who are responsible for managing the entire network (manufacturers who purchase their products, such as in the automotive industry).

\subsection{Quality Management Systems}

Companies were evaluated according to the quality management systems that date adopt. This information refers to systems that apply within the organization, regardless of the network as a whole. The results are shown in Figure 5.

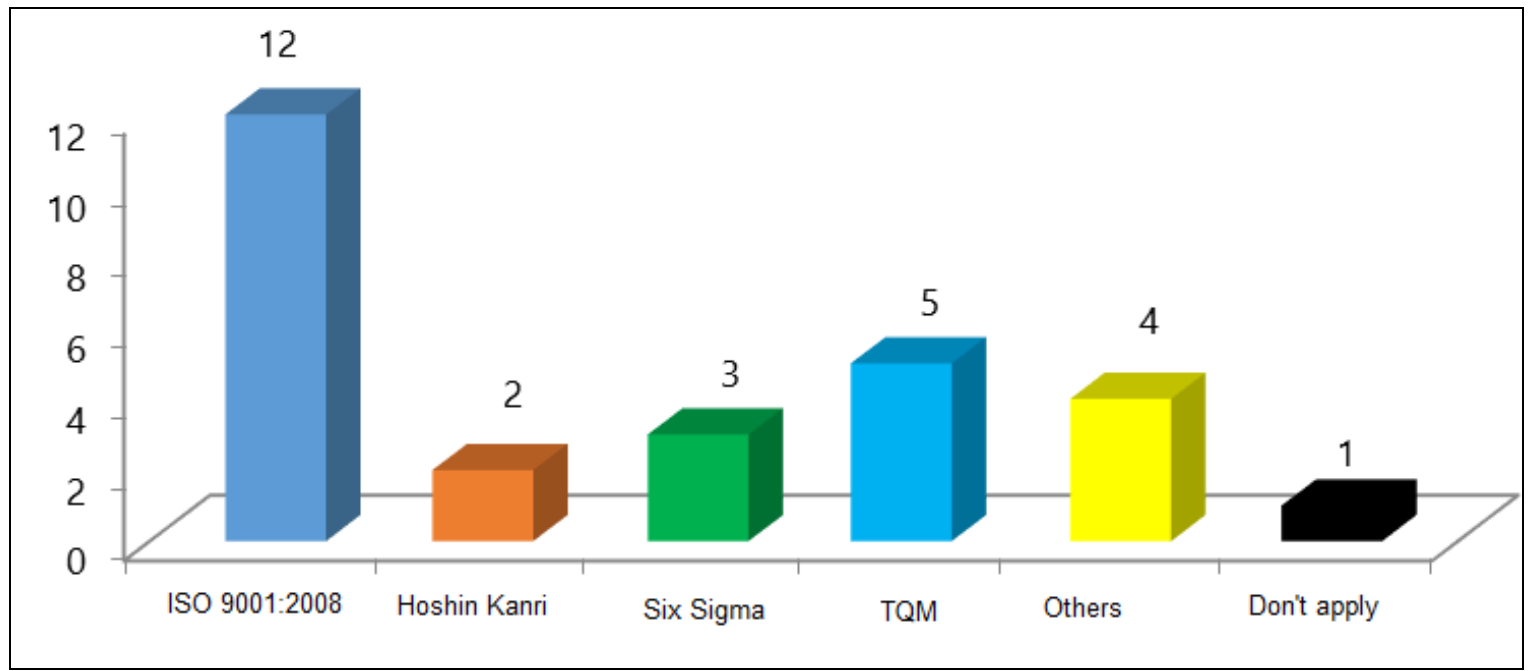

Figure 5: Quality Management Systems Adopted by Companies.

The research identified that the quality management system that was most used was ISO 9001. Of course, this rule is widespread globally, which leads it to be used by a majority of businesses. In many sectors, this standard is mandatory for 
INDEPENDENT JOURNAL OF MANAGEMENT \& PRODUCTION (IJM\&P) http://www.ijmp.jor.br

v. 5, n. 2, February - May 2014. ISSN: 2236-269X

DOI: 10.14807/ijmp.v5i2.146

suppliers. At present, final consumers recognize this standard as a way to guarantee the quality of products and services from organizations.

The other quality management systems were cited equivalently, but none were present in more than $30 \%$ of the sample. Some organizations reported using other quality assurance systems which were specific to the specific sector in which they operate. Only the food manufacturer said that it did not adopt a specific system of quality management, although it is a well-established company. According to the company, its market share is approximately $17 \%$, and operates in the southeast region of Brazil only. This may be an important factor in the company not yet having assessed the need to adopt a quality management system. Of the companies researched, $77 \%$ considered their quality management system either excellent or good.

In relation to its suppliers of raw materials, equipment and services, the companies said that they adopted quality assurance controls for these suppliers in their supply network. These systems are identified in Figure 6.

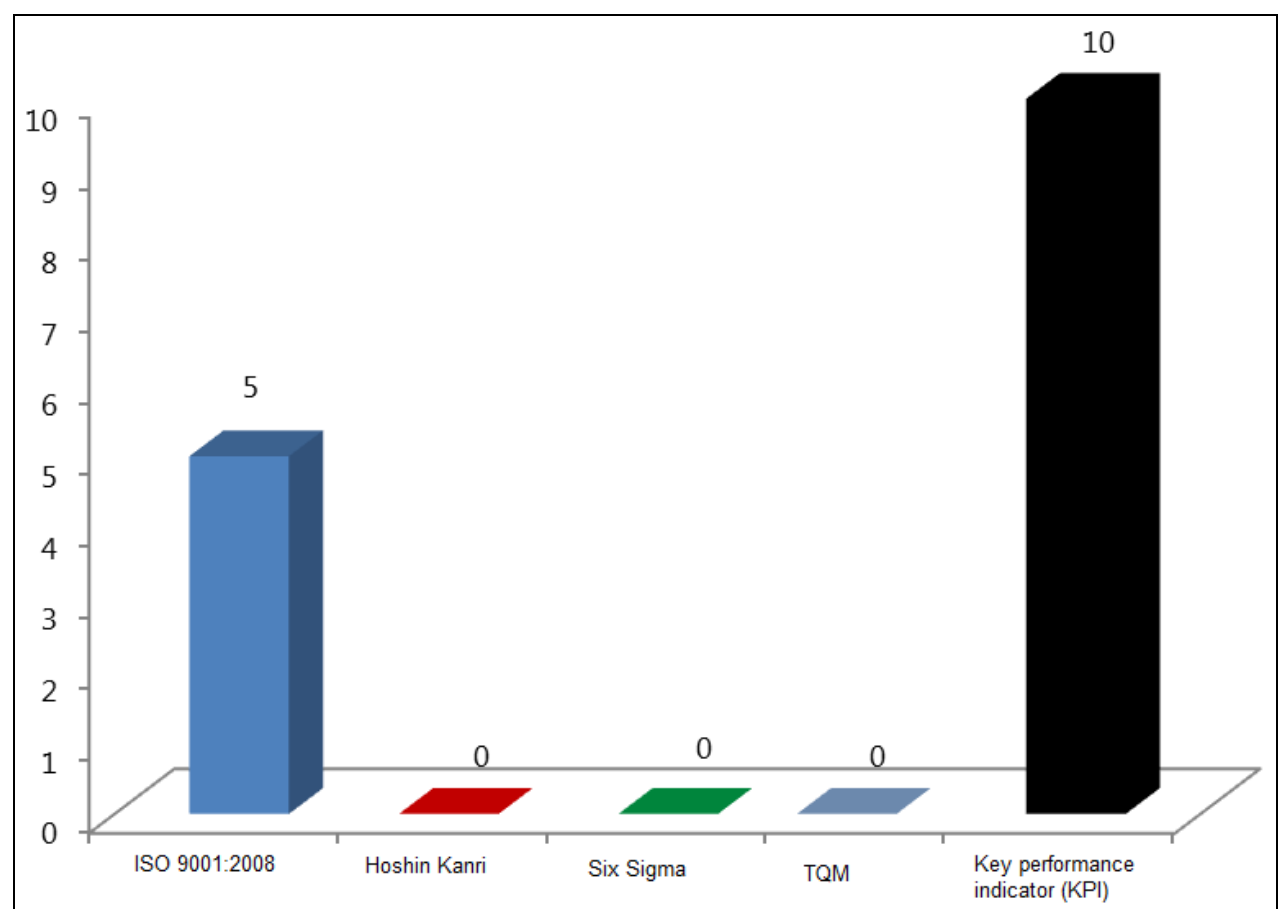

Figure 6: Quality Assurance Systems for Providers of Products and Services.

In order to ensure quality from suppliers of products and services, the companies surveyed mostly adopt internal systems for approval of suppliers and create performance indicators for monitoring them. Other companies use ISO certification as a way to ensure such quality. Only two companies said they had 
INDEPENDENT JOURNAL OF MANAGEMENT \& PRODUCTION (IJM\&P)

special systems to ensure the quality of product suppliers (raw materials and equipment) and service providers. For the former, they use ISO 9001:2008 and, for the latter, they use performance indicators.

It can be inferred that for the suppliers in the supply network to ensure that they will be able to provide their products and services, these must meet the requirements of the customers. It follows therefore, that it may be more important to follow these requirements than effectively adopt a quality assurance standard, though this may well be mandatory in some sectors.

\subsection{Analysis of the results}

The survey conducted at the companies enabled a practical analysis of how they have implemented supply chain management and applied quality management systems. The results showed that organizations do not have the SCM model as standard for their operations. It can be seen that there is still a considerable presence of process verticalization in some organizations, with a view to satisfying the consumer market.

Concerning to quality management systems, research has shown that these are well established within organizations individually, with in many cases more than one quality management system being used. However, it can be seen that Standard ISO 9000 is the one which is predominant in companies, one reason being that it is better known by customers. However, it can be seen that when it comes to the quality of suppliers which belong to the supply network, the quality management systems are not used in the same way as within individual companies. In general, indicators are established instead of adopting a formal system for quality management, and an advance in the use of ISO Standards by suppliers can be observed, essentially in those organizations are the hubs of the networks in which they participate.

Therefore, it is possible to infer that the migration of quality management systems across the supply chain with a view to full SCQM is still a process that is in need of further improvement and development. Organizations have different standards for their suppliers from those which they use inside their own installations, the conditional factor being mainly the difficulty of obtaining suppliers, such as in the 
INDEPENDENT JOURNAL OF MANAGEMENT \& PRODUCTION (IJM\&P) http://www.ijmp.jor.br

case of the automotive industry, which has trouble obtaining suppliers for seats for their vehicles, which leads to less strict control of the quality of these.

\section{CONCLUSION}

This study has aimed to demonstrate the implementation of the concepts of quality management systems over the entire supply chain, addressing the evolution of the concept from within individual companies to encompassing the different actors in the network. The results of the survey conducted in companies operating in Brazil have shown that SCQM is still at an embryonic stage, although it was found that it is mandatory for an ever growing number of suppliers, to comply with the requirements of the quality management systems of the network hub companies.

We believe that this work has contributed to spreading the concepts of SCQM and assisted in the analysis of its application, demonstrating to entrepreneurs, researchers and customers all the work that still needs to be done, so that the quality can be the same throughout the network.

Furthermore, the objective of this paper was achieved. The work showed concepts of supply networks, supply chain quality management and their relationship that quality management systems and their empirical applicability in thirteen companies acting in Brazil.

\section{REFERENCES}

AKPOLAT, H. (2004) Six Sigma in non-manufacturing environments. The Asian Journal of Quality, v. 5, n. 2, p. 17-25.

BEAMON, B. M.; WARE, T. M. (1998) A process quality model for the analysis, improvement and control of supply chain systems. Logistics Information Management, v. 11, n. 2, p. 105-113.

CAMPOS, V. F. (2004). TQC - controle da qualidade total no estilo japonês, 8 ed. Nova Lima: INDG Tecnologia e Serviços LTDA.

CARMIGNANI, G. (2009). Supply Chain and Quality Management: the definition of standard to implement a process management system in a supply chain. Business Process Management Journal, v. 15, n. 3, p. 395-407.

CHOPRA, S.; MEINDL, P. (2011). Gerenciamento da cadeia de suprimentos: estratégia, planejamento e operação, 4 ed. São Paulo: Prentice Hall.

CHRISTOPHER, M. (2011). Logística e gerenciamento da cadeia de suprimentos, 3 ed. São Paulo: Cengage Learning.

CORRÊA, H. L. (2010). Gestão de redes de suprimento, São Paulo: Atlas. 
INDEPENDENT JOURNAL OF MANAGEMENT \& PRODUCTION (IJM\&P)

COSTA NETO, P. L. O.; CANUTO, S. A.(2010). Administração com qualidade, São Paulo: Blucher.

COSTA NETO, P. L. O. (2007). Decisões na gestão da qualidade, in: COSTA NETO, P. L. O. Decisões com qualidade. São Paulo: Bluncher.

FEIGENBAUM, A. V. (1994) Controle da qualidade total. São Paulo: Makron Books.

FERREIRA, J. J. D. A. (2005). Modelos normalizados de sistemas de gestão. Conceitos e certificação: ISO 9001; ISO 14001 e TS 16949, in: CARVALHO, M.M.D.; PALADINI, E. P. Gestao da Qualidade: teoria e casos. São Paulo: Campus Abepro, p. 153-186.

FEDERAÇÃO DAS INDÚSTRIAS DO ESTADO DE SÃO PAULO (2013). Data base. Available at: www.fiesp.com.br. Accessed in January, 21, 2013.

FOSTER JR., S. T. (2008). Towards an understanding of supply chain quality management. Journal of Operations Management, n. 26, p. 461-467.

HUR, M. H. (2009). The influence of Total Quality Management practices on the transformation of how organisations work. Total Quality Management, v. 20, n. 8, p. 847-861.

INSTITUTO BRASILEIRO DE GEOGRAFIA E ESTATÍSTICA. (2007). Classificação nacional de atividades econômicas. Rio de Janeiro: IBGE.

INTERNATIONAL ORGANIZATION FOR STANDARDIZATION. (2013). Data base. Available at: <http://www.iso.org/iso/about.htm>. Accessed in February, 10, 2013.

KAYNAK, H.; HARTLEY, A. (2008). A replication and extension of quality management into supply chain. Journal of Operations Management, v. 26, p. 468489.

KUEI, C. H.; MADU, C. N.; LIN, C. (2001). The relationship between supply chain quality management practices and organizational performance. International Journal of Quality \& Reliability Management, v. 18, n. 8, p. 864-872.

LIN, C.; CHOW, W. S.; MADU, C. N.; KUEI, CH; YU, P. P. (2005). A structural equation model of supply chain quality management and organizational performance. International Journal of Production Economics, v. 96, p. 355-365.

LIN, C.; KUEI, C.; CHAI, K. (2013). Identifying critical enablers and pathways to high performance supply chain quality management. International Journal of Operations \& Production Management, v. 33, n. 3, p.347-370.

MEHRJERDI, Y. Z. (2011) Six-Sigma: methodology, tools and its future. Assembly Automation, v. 31, n. 1, p. 79-88.

MIGUEL, P. A. C. (2006) Gestão da Qualidade: TQM e modelos de excelência, in: CARVALHO, M.M.; PALADINI, E.P. (Org). Gestão da Qualidade: teoria e casos. São Paulo: Campus - Abepro, p. 85-124.

PIRES, S. R. I. (2009). Gestão da cadeia de suprimentos, 2 ed. São Paulo: Atlas.

ROBINSON, C. J.; MALAHOTRA, M. K. (2005). Defining the concept of supply chain quality management and its relevance academic and industrial practice. International Journal of Production Economics, v. 96, p. 315-337. 
SAMPAIO, P.; SARAIVA, P.; RODRIGUES, A. G. (2009). ISO 9001 certification research: questions, answers and approaches. International Journal of Quality \& Reliability Management, v. 26, n. 1, p. 38-58.

SILA, I.; EBRAHIMPOUR, M.; BIRKHOLZ, C. (2006). Quality in supply chains: an empiracal analysis. Supply Chain Management, v. 6, n. 11, p. 491-502.

$\mathrm{ZU}, \mathrm{X}$.; KAYNAK, H. (2012). An agency theory perspective on supply chain quality management. International Journal of Operations \& Production Management, v. 32 , n. 4 , p. $423-446$. 